\title{
Destinasyon Çekim Gücü Olarak Gastronomi Müzeleri: Safranbolu Türk Kahve Müzesi Örneği
}

\author{
Öğr. Gör. Elif Cemre BOZAGCI \\ Doğuş Üniversitesi \\ Sanat ve Tasarım Fakültesi \\ ebozagci@dogus.edu.tr \\ https://orcid.org/0000-0003-1574-5120
}

DOI: https://doi.org/10.37847/tdtad.1016819

Makale Gönderim Tarihi: 24.11.2021

\author{
Öğr. Gör. Alper ÇEViK \\ Kastamonu Üniversitesi \\ Daday Nafi ve Ümit Çeri Meslek Y.O. \\ alpercevik@kastamonu.edu.tr \\ https://orcid.org/0000-0002-6627-8246
}

Makale Türü: Araştırma Makalesi

Makale Kabul Tarihi: 10.12.2021

Özet

Amaç: Safranbolu Türk Kahve Müzesi'nin bulunduğu destinasyon için çekicilik unsuru olarak değerlendirilebilirliğinin ölçülmesi ve bu bağlamda unutulmaya yüz tutmuş Türk kahvesi kültürünü korumak, tanıtmak ve sürdürülebilirliğini sağlamak amacıyla kurulan Safranbolu Türk Kahve Müzesi'nin Safranbolu turizminin gelişmesine sağladığı katkıyı incelemektir.

Yöntem: Çalışma nitel veri toplama yöntemlerinden görüşme tekniği ile hazırlamıştır. Müze sahibi ve kurucusu ile yapılan görüşmede yarı yapılandırılmış form kullanılmıştır.

Bulgular: Safranbolu Türk Kahve Müzesi'nde Türk kültürünün önemli unsurlarından biri olan Türk kahvesinin hazırlanışından tüketimine uzanan tüm süreç misafirlere anlatılmakta ve tanıtılmaktadır. Yıl içerisinde yurt içi ve yurt dışından çok sayıda ziyaretçiyi ağırlayan müzede Türk kahvesi kültürü tanıtılmaktadır. Türk kahvesinin somut olmayan kültürel miras listesine dahil edilen ilk içecek olması, müzede geçmişten günümüze Türk kahvesi hazırlanmasında kullanılan ekipmanların sergilenmesi ve Türk kahvesine inovatif bir yaklaşım olarak değerlendirilen safranlı Türk kahvesi servis edilmesi müzeyi çekici kılan etkenlerdir. Müzenin tanıtımı için dijital platformlar, ulusal ve uluslararası fuarlar, şehirdeki diğer paydaşlarla iş birlikleri yapılmakta ve müze turistik tur programlarına dahil edilmektedir.

Tartışma: Safranbolu Türk Kahve Müzesi örneğinde görüldüğü gibi gastronomi müzeleri kültürel unsurların korunması, tanıtılması ve gelecek nesillere aktarılmasında önemli bir rol oynamaktadır. Hem Türk mutfağına özgü unsurların tanıtılması ve korunması hem de destinasyonların turistler açısından daha çekici hale getirilmesi gastronomi müzelerinin en büyük avantajlarıdır. Bu sebeple gastronomi müzeleri ile ilgili akademik çalışmaların arttırılması, yöresel ve geleneksel ürünlerin korunması ve tanıtılması için yeni gastronomi müzelerinin kurulması için gerekli çalışmaların yapılmasının önemli olacağı düşünülmektedir.

Anahtar Kelimeler: Destinasyon çekiciliği, Gastronomi müzeleri, Safranbolu Türk Kahve Müzesi

\section{Gastronomy Museums As Destination Attraction: Safranbolu Turkish Coffee Museum}

\section{Abstract}

Purpose: To measure the efficacy of Safranbolu Turkish Coffee Museum as an element of attraction for the destination and to examine the contribution of the Safranbolu Turkish Coffee Museum, which was established to protect, promote and sustain the Turkish coffee culture that has sunk into oblivion, to the development of Safranbolu tourism. 
Method: The study was prepared with the interview technique, one of the qualitative data collection methods. A semi-structured form was used in the interview with the owner and founder of the museum.

Findings: In Safranbolu Turkish Coffee Museum, the whole process from preparation to consumption of Turkish coffee, which is one of the important elements of Turkish culture, is explained and introduced to the guests. Turkish coffee culture is introduced in the museum, which welcomes many visitors from home and abroad throughout the year. The fact that Turkish coffee is the first beverage included in the list of intangible cultural heritage, the equipment used in the preparation of Turkish coffee from past to present in the museum, and the serving of Turkish coffee with saffron, which is considered an innovative approach to Turkish coffee, are the factors that make the museum attractive. For the promotion of the museum, digital platforms, national and international fairs, cooperation with other stakeholders in the city are made and the museum is included in touristic tour programs.

Discussion: As seen in the example of Safranbolu Turkish Coffee Museum, gastronomy museums play an important role in preserving, promoting and transferring cultural elements to future generations. The biggest advantages of gastronomy museums are both to introduce and protect the elements specific to Turkish cuisine and to make destinations more attractive for tourists. For this reason, it is thought that it will be important to carry out the necessary studies for the establishment of new gastronomy museums in order to increase academic studies on gastronomy museums, to protect and promote local and traditional products.

Keywords: Destination attraction, Gastronomy museums, Safranbolu Turkish Coffee Museum

\section{Giriş}

Beslenme, canlıların hayatta kalabilmeleri için en temel fizyolojik ihtiyaçlardan biri olarak kabul edilse de aynı zamanda sosyal ve kültürel yapıya sahip bir olgu olarak değerlendirilmektedir (Quan ve Wang, 2004). Toplumların tarihsel süreç boyunca yiyecek ve içeceklere yaklaşımlarının tümü bugün sahip oldukları mutfak kültürünü meydana getirmektedir. Aynı zamanda bu yaklaşımlar içinde yer alan aletler, kap ve kacaklar, pişirme teknikleri, gelenekler, ritüeller de mutfak kültürünü şekillendiren unsurlar olarak kabul edilmektedir (Çetin ve Küçükkömürler, 2019). Daha önce fizyolojik bir ihtiyaç ve biyolojik bir eylem olarak görülen yemek yeme eyleminin kültürel kısmına ilgi son derece az iken son dönemlerde bu anlayışın ötesine geçilmiş ve yeme içmeye dair her türlü alışkanlık kültürleri temsil eden ögelerden biri haline gelmiştir (Gökdeniz, Erdem, Dinç ve Çelik Uğuz, 2015).

Gastronomi sahip olduğu farklı kültürel ürünleri birleştiren yapısı sayesinde turizmde önemli bir yer edinmiştir (Ağcakaya ve Can, 2019). Yeme içme olgusunun kültürel kısmina artan ilgiyle birlikte gastronomi unsuru destinasyonların turistler tarafından tercih edilme sebebi haline gelmiştir (Mankan, 2017a). Bu durum gastronomi turizmi adı verilen yeni bir turizm şeklini ortaya çıkarmıştır. Gastronomi turizmi, yeme içme deneyimi yaşamak için genellikle yerel yiyeceklerin bulunduğu destinasyonlara gerçekleştirilen turizm etkinliği olarak açıklanmaktadır (Cömert ve Sökmen, 2017). Bir başka deyişle; gastronomi turizmi temel motivasyonu spesifik bir yemeği veya mutfak kültürünü keşfetmek olan, farklı bir bölgede yer alan yiyecek üreticisi, restoran, festival veya özel alanları ziyareti kapsayan turizm hareketliliğidir (Yüncü, 2010). Gastronomi turizmi sadece seyahat edilen bölgenin kültürel yemeklerinin yenmesinden ziyade o 
kültürün mutfağını, tüketilen yiyeceklerin hazırlanması ve sunulması aşamalarını, tüketim şekillerini kısaca mutfak alışkanlıklarını keşfetmek ve deneyimlemeyi kapsamaktadır (Long, 2004; Yıldız ve Yılmaz, 2019). Gastronomi müzeleri ise gastronomi turizminin en önemli unsurlarından biri olarak kabul edilmektedir. Ayrica gastronomi müzeleri kültürel etkinlik kapsamında çok sayıda kişinin ziyaret etmesi sebebiyle turizm sektöründe de önemli bir yer tutmaktadır.

Toplumsal kimliğin bir parçası olan müzeler kültürel mirasın korunması ve gelecek nesillere aktarılmasında aktif rol oynayan kurumlardır (Köroğlu, Balıkoğlu, Köksalanlar ve Türkmen, 2020). Milletlerarası Müze Konseyi müzeleri "Kültür eserlerini koruyan ve bu eserleri etüd, eğitim ve bedii zevki yükseltme amacıyla toplu halde teşhir eden kamu yararına çalışan, sanata, ilme, sağlığa, teknolojiye, ait koleksiyonları bulunan müesseselere müze adı verilir." şeklinde tanımlamaktadır (Resmî Gazete, 1985).

Son dönemlerde gastronomi mirasının korunması, tanıtılması ve gelecek nesillere aktarılması kültürel olarak önemli bir konumdadır. Gastronomi turizmi kapsamında seyahat eden turistler sadece bölgenin kültürel yemeklerini tatmak değil aynı zamanda bu yemeklerin tarihi, hazırlanması ve sunumu ile ilgili de bilgi sahibi olmak istemektedirler (Bekar, Arman ve Sürücü, 2017). Bu noktada gastronomi müzeleri turistlere kültürel yemeklerin her aşamasını ve mutfak kültürünü detaylı bir biçimde aktarabilecek mekanlardır. Geçmiş ile gelecek arasında köprü vazifesi gören müzelere gastronomi açısından bakıldığında ulusların kültürel mutfak mirasının korunması, tanıtılması ve geleceğe aktarılmasında gastronomi müzelerinin önemli bir rolü vardır (Akyürek ve Erdem, 2019).

Çalışmanın amacı Safranbolu Türk Kahve Müzesi'nin bulunduğu destinasyon için çekicilik unsuru olarak değerlendirilebilirliğinin ölçülmesi ve bu bağlamda unutulmaya yüz tutmuş Türk kahvesi kültürünü korumak, tanitmak ve sürdürülebilirliğini sağlamak amacıyla kurulan Safranbolu Türk Kahve Müzesi'nin Safranbolu turizminin gelişmesine sağladığı katkıyı incelemektir. Çalışma, nitel veri toplama tekniklerinden görüşme yöntemi ile hazırlanmıştır. Yarı yapılandırılmış form aracılığıyla gerçekleştirilen görüşme sonucunda elde edilen veriler gastronomi turizmi ve destinasyon çekim gücü çerçevesinde değerlendirilmiştir. Alanyazında daha önce Safranbolu Türk Kahve Müzesi'nin destinasyon çekicilik unsuru kapsamında değerlendirildiği herhangi bir çalışmaya rastlanmadığından konusu bakımından özgün olan çalışmanın, Safranbolu'yu turizm açısından üne kavuşturan kültür turizmi, mağara turizmi ve yayla turizmi unsurlarının yanında ziyaretçileri bölgeye çekebilecek yeni bir turistik ilgi noktası olması konusunda farkındalık yaratması hususunda önemli olduğu düşünülmektedir.

\section{Kavramsal Çerçeve}

\section{Gastronomi Müzeleri}

Destinasyonların turistler açısından tercih sebebi olarak görülmesi sahip olduğu çekiciliklerle ilişkilidir. Destinasyonun sahip olduğu doğal güzellikler, imajı, ulaşım ve konaklama imkanları gibi unsurların her biri destinasyonlar için birer çekicilik unsuru olarak değerlendirilmektedir (Yeşilyurt ve Arıca, 2018). Son dönemlerde farklı turizm 
çeşitlerine artan ilgi gastronominin seyahat motivasyonları içinde öne çıkmasını sağlamıştır. Gastronomiye ait yiyecek içecek, mutfak kültürü, yemek festivalleri, restoranlar, müzeler gibi tüm unsurların destinasyonlar için temel çekicilik unsuru haline gelmesiyle birlikte gastronomi turizmi kavramı ortaya çıkmıştır (Gök ve Şalvarcı, 2021). Gastronomi turizmi kavramı genel olarak yiyecek içecek deneyimi yaşamak için gerçekleştirilen seyahat olarak tanımlansa da seyahat edilen destinasyona ait yeme içme alışkanlıkları, özel gün ve kutlamalarda tüketilen yiyecek içecekler, bu yiyecek içeceklerin geleneksel sunum şekilleri gibi mutfak kültürünü yansitan birçok unsur da gastronomi turizminin motivasyonları içinde yer almaktadır (Küçükkömürler, Şirvan ve Sezgin, 2018).

Müzeler destinasyonlar açısından kültürel bir çekicilik unsuru olarak kabul edilmektedir. Bu bağlamda gastronomi turizminin en değerli öğelerinden biri olan gastronomi müzelerinin sayısı gastronomi turizmine ilginin artmasıyla birlikte artmaya başlamıştır (Sandıkçı, Mutlu ve Mutlu, 2019). Özellikle köklü bir tarihi geçmişe sahip destinasyonların tarihi ve kültürel miraslarını koruyarak bu mirasları turistlerin ziyaretlerine açması tüm dünyada dikkat çekerek turistlerde ziyaret etme niyeti oluşturmaktadır (İpar, 2011). Bu açıdan bakıldığında gastronomi müzeleri, turistleri gastronomi turizmine teşvik eden ve bulunduğu destinasyonun çekiciliğini artırarak destinasyon pazarlamasında önemli taşıyan bir unsur olarak kabul edilmektedir (Mankan, 2017b).

Alanyazına bakıldığında turizm ve gastronomi ilişkisi üzerine birçok çalışma yapıldığ görülmektedir. Bu çalışmalardan bazılarında gastronomi turizminin turistler üzerindeki etkisini, bazılarında turistlerin destinasyonlarda yaşadıkları gastronomi deneyimini bazılarında ise gastronomi müzelerinin destinasyon çekicilik unsuru olarak ele alındığ 1 görülmektedir (Kaşlı, Demirci ve Kement, 2014; Yılmaz, 2017; Çetin ve Küçükkömürler, 2019; Ağcakaya ve Can, 2019; Özdemir ve Dülger Altıner, 2019) Bu çalışmalardan gastronomi müzelerini destinasyon çekim gücü olarak değerlendiren çalışma sayısının oldukça az olduğu görülmüştür.

Türkiye'de kurulan ilk mutfak müzesi 2008 yılında kültür turizmi kapsaminda Gaziantep'te kurulan Emine Gögüuss Mutfak Müzesi'dir (Türkiye Kültür Portalı). Daha sonra her geçen yıl sayısı artan gastronomi müzelerinin bazılarında tek bir gıda (dondurma, baklava, kahve, çikolata) tema olarak seçilirken bazılarında ise mutfak kültürünün tamamının sergilendiği görülmektedir (Sandıkçı, Mutlu ve Mutlu, 2019). Gastronomi müzeleri bulunduğu destinasyonun kültürünü ve gastronomi mirasını turistler için önemli bir deneyim haline getirmektedir. Gastronomi müzeleri aracılığıyla bölgenin mutfak mirası turistlere tanıtılırken aynı zamanda bölge turizmi sürdürülebilir hale getirilmekte ve bölgeye ekonomik ve sosyal açıdan katkı sağlanmaktadır (Çavuş, Işık ve Yalçın, 2018).

\section{Kahve}

Kahve Rubiaceae familyasına ait olan ve 120'ye yakın türe sahip bir bitkidir. Bu türlerin içinde en bilinenleri ve en önemlileri Arabica ve Robusta türleridir. Dünyada kahve üretiminin büyük bir çoğunluğu bu iki türden meydana gelmektedir (Girginol, 2018). Kahvenin nasıl keşfedildiğine dair kesin bir bilgi bulunmamakla birlikte, bu 
hususla ilgili birçok rivayet ortaya atılmıştır. Bunlardan en bilineni Yemenli çoban Khaldi'nin hayvanların garip davranışlarının nedenini araştırırken bazı yeşil ve sarı meyveleri tükettiklerini fark etmesi ve kendisinin de bu meyvelerden bir içecek hazırlayarak tüketmesi ile kahvenin keşfedilmiş olmasıdır (Balcı, 2019).

Kahve bitkisinin geçmişi bugün Etiyopya ve Kenya'nın yer aldığı orta ve batı Afrika' ya kadar uzanmaktadır. Başlangıçta kahve bitkisinin meyvelerinin bu bölgelerde bir bütün halinde veya kırılarak yağ ile karıştırılarak tüketilmekteydi (Gürsoy, 2005). Bu bölgelerden Yemen'e gelen kahvenin üretimi ilk kez burada gerçekleştirilmiş daha sonra savaşlar, göçler, ticaret gibi yollarla tüm dünyaya yayılarak dünya çapında bir içecek haline gelmiştir (Kaya ve Toker, 2019).

Kahvenin İstanbul'a gelişi XV. yüzyıl sonları XVI. Yüzyıl başlarına tarihlenmektedir (Ürer, 2010). Osmanlı Devleti'nin kahve ile tanışması ile ilgili de birkaç rivayet mevcuttur. Bu rivayetlerin ilkine göre Kabe'ye hacca giden hacıların dönerken yanlarında kahve getirmesiyle kahve ilk kez İstanbul'a gelmiştir. İkinci rivayete göre ise Yavuz Sultan Selim'in Mısır seferinde kahve ile tanıştığ 1 ve dönerken yanında kahve getirdiği bilinmektedir (Acar, Çakırbaş ve Çizmeci, 2019). Zaman içerisinde tüketimi yaygınlaşan kahve herhangi bir içecek olmaktan ziyade sosyal yaşamın bir parçası haline gelmiştir (Arslan, 2019). İlk kez Türkler tarafından uygulanan cezve veya gügü̈mde pişirme tekniği ile hazırlanan kahve tüm dünyada Türk kahvesi olarak bilinmektedir (Kefeli, Şahin ve Yarmacı, 2020). Osmanlı döneminden günümüze uzanan süreçte Türk mutfağının vazgeçilmez bir parçası haline gelen kahve kültürel açıdan Türk mutfağının en önemli unsurlarından biri olarak görülmektedir. (Temeloğlu ve Akdeniz, 2020).

Türk toplumunun gelenek ve ritüellerinde de yer edinen Türk kahvesi yaklaşı 500 yıllık geçmişiyle Türk kültürünün en bilinen unsurlarından biri haline gelmiştir. Tüm dünyada Türk kahvesi olarak bilinmesi sebebiyle Türk kültürünün bir parçası haline gelen Türk kahvesi 2013 yılında UNESCO tarafından somut olmayan kültürel miras listesine alınmıştır (Koca ve Ersöz Tüğen, 2020).

\section{Dünya'da Kahve Müzeleri}

Kahve tüm dünyada sevilen ve sıkça tüketilen bir içecek olmasının yanı sıra köklü bir tarihe sahip olması ile de bilinmektedir. Dünyada kahve kültürünü korumak, tanıtmak ve gelecek nesillere aktarabilmek için kurulmuş birçok kahve müzesi mevcuttur (Ceyhun Sezgin ve Akbiyuk, 2021).

Bu müzelerden ilki 1992 yılında Londra'da Edward Bramah tarafından kurulan Bramah Tea and Coffee Museum'dur. Müze çay ve kahve olarak iki bölüme ayrılmıştır. Müzenin kahveye ayrılan kısmında ziyaretçiler kahvenin İngiltere'ye gelişi, yetiştirilmesi, hasadı, öğütülmesi gibi hususlarda bilgilendirilmektedir (Halstead, Hazeley, Morris ve Morris, 2007).

Bir diğer kahve müzesi Brezilya'nın Santos şehrinde yer alan Brazil's Coffee Palace'dır. 1914 yılında Resmi Kahve Borsası Sarayı olarak kullanılan yapı 1950 yılına kahve çekirdeklerinin fiyatının belirlendiği yer olarak kullanılmaktaydı. Müzede eski dönemlerden kalan kahve çuvalları, teraziler, tartım masaları ve bunlara ait fotoğraflar 
yer almaktadır. Ayrıca müzenin giriş katında ziyaretçilerin Brezilya'nın farklı bölgelerinden gelen kahvelerin tadabileceği bir kafe yer almaktadır (Atlas Obscura, 2021).

Dubai'de yer alan kahve müzesi Arap kahvesi olarak bilinen gahwayı tanitma amaciyla kurulmuştur. Hediyelik eşyalardan antik cezvelere varan geniş bir koleksiyona sahip olan müzede ziyaretçilerin yerel ve ulusal kahveleri tadabileceği bir kahve barı mevcuttur (Sun ve McLaughlin-Eastham, 2019).

Bunlara ek olarak dünya genelinde Japonya' da UCC Coffee Museum, Hindistan'da Coffee Museum, Vietnam'da The World Coffee Museum, Çek Cumhuriyeti'nde Coffee Museum Prag, Rusya'da Muzey Kofe ve Malezya'da Chocolate and Coffee Museum gibi birçok kahve müzesi mevcuttur.

\section{Yöntem}

Çalışma Karabük ilinin Safranbolu ilçesinde yer alan Safranbolu Türk Kahve Müzesi'nde gerçekleştirilmiştir. Safranbolu Türk Kahve Müzesi, Türk kahvesinin çekirdekten fincana uzanan tüm süreçlerinin ziyaretçilerle paylaşıldığı, bu süreçler boyunca kullanılan ekipmanlarının sergilendiği, ziyaretçilerine Anadolu'nun birçok bölgesinde farklı şekillerde hazırlanan kahveleri tatma imkanı sunan kahve temalı bir müzedir. Çalışma nitel araştırma yöntemlerinden görüşme tekniği kullanılarak hazırlanmıştır. Çalışmada elde edilen veriler 15 Kasım 2021 tarihinde Safranbolu Türk Kahve Müzesi'nin kurucusu ve işletmecisi Semih Yıldırım ile Safranbolu Türk Kahve Müzesi'nde gerçekleştirilen görüşme esnasında elde edilmiştir. Görüşmede veri toplama aracı olarak yarı yapılandırılmış form kullanılmıştır. Türkiye' de kahve müzesi kavramının yeni bir kavram olması, Safranbolu Türk Kahve Müzesi'nin ilk ve tek olma özelliğine sahip olması ve bu müze ile ilgili yapılmış herhangi bir akademik çalışmaya rastlanmaması çalışmanın sinırlılıklarını oluşturmaktadır. Görüşmede veri toplama aracı olarak kullanılan yarı yapılandırılmış form alanyazında yer alan gastronomi müzeleri üzerine yapılan çalışmalardan yola çıkılarak (Bekar vd, 2017; Çetin ve Küçükkömürler, 2019; Çavdırlı ve Gök, 2020) hazırlanmış ve bu doğrultuda Safranbolu Türk Kahve Müzesi kurucusu ve işletmecisi Semih Yıldırım'a şu sorular yöneltilmiştir;

1. Safranbolu Türk Kahve Müzesi'nin kuruluş amacı nedir?

2. Müzeye y1llık ne kadar ziyaretçi geliyor ve gelen ziyaretçilerin sosyo-demografik özellikleri nelerdir?

3. Müzenin bir bölümünde ziyaretçilerin tüketebilecekleri kahve çeşitleri sunuyorsunuz. Bu kahve çeşitlerini neye göre seçiyorsunuz?

4. Safranbolu için Türk kahvesini ve Safranbolu Türk Kahve Müzesi'ni çekici kılan özellikler nelerdir?

5. Müzeyi tanıtmak ve turizme açmak için ulusal ve uluslararası düzeyde hangi faaliyetleri yürütüyorsunuz?

6. Safranbolu Türk Kahve Müzesi tur şirketlerinin gezi programlarına dahil midir? 
Yaklaşık 1 saat süren görüşme araştırmacılar tarafından ses kaydına alınmış, daha sonra değiştirilmeden yazılı metne dönüştürülmüştür.

\section{Bulgular}

Safranbolu Türk Kahve Müzesi kurucusu ve işletmecisi Semih Yıldırım ile yapılan görüşmeden elde edilen veriler aşağıda sunulmuştur.

\section{Safranbolu Türk Kahve Müzesi'nin kuruluş amacı nedir?}

Türk kahvesi sahip çıkılması gereken çok önemli bir değer. Türk kahvesi ülkemizde yetişmemesine rağmen pişirme yönteminden ötürü bu adı alarak dünyaca ünlü bir marka haline gelmiş bir ürün. Ayrıca petrolle beraber en fazla ticareti yapılan ürün olması kahvenin aynı zamanda iyi bir pazarı olduğunu da gösteriyor. Dolayısı ile hem maddi hem de manevi değeri var. Türkler için oldukça önemli ve sevilen bir içecek olan Türk kahvesinin tanıtımını ülke olarak tam anlamıyla yapamadığımızı düşünüyorum. Dünyada kahve müzelerine sahip olan Vietnam gibi ülkelere bakıldığında bu müzelerde kendi kültürlerini tanıttıklarını da görüyoruz. Ancak tüm dünyada Türk kahvesi olarak bilinen içeceğin müzesinin olmadığını düşündüğümüzde, Türk kahvesinin üreticisi de olarak Türk kahvesi kültürünün tanıtılması, gelecek kuşaklara aktarılması kapsamında Türkiye'de ilk ve tek olan Türk kahve müzesinin kurulmasına karar verdik.

Müzeye yıllık ne kadar ziyaretçi geliyor ve gelen ziyaretçilerin sosyo-demografik özellikleri nelerdir?

2019 yılının Mart ayında başlayan salgın döneminden önceki zaman baktığımızda yıllık 150-200 bin civarında ziyaretçi geldiğini söyleyebiliriz. Her kesimden her yaştan kahveyi merak eden ilgi duyan yerli ve yabancı ziyaretçileri ağırlıyoruz. Bunun yanında kahveye ilgi duymayan, tüketmeyen misafirler bir şekilde kahve müzesini gezdiklerinde kahveye olan ilgilerinin arttığını ve kahve içmek istediklerini görüyoruz. Ayrıca yabancı ülkelerin devlet adamlarını ağırlayarak kültürümüzü tanıtmada önemli bir misyon yükleniyoruz. Yabancı ziyaretçilerin büyük bir kısmı özellikle Uzak doğulu misafirlerimizden oluşuyor. Ancak son dönemlerde Avrupa ülkelerinden gelen ziyaretçilerimizin de sayısında artış yaşanmaya başladı. Müzemize gelen yerli turistlere baktığımızda ise Türkiye'nin her yerinden ziyaretçilerimiz olduğunu söyleyebiliriz. Özellikle müzemizi ziyaret eden yabancı kahve işletmecilerinin sayısının arttığı bu dönemlerde Z kuşağının ilgisini ve merakını çekebildik.

Müzenin bir bölümünde ziyaretçilerin tüketebilecekleri kahve çeşitleri sunuyorsunuz. Bu kahve çeşitlerini neye göre seçiyorsunuz?

Öncelikle Anadolu'da yapılmış fakat unutulmaya yüz tutmuş "Nohut”, "Zingarella”, “Tarz-1 Hususi", "Burçak", "Cilveli", "Mırra”, “Dibek", "Şehzade" ve "Hilve” gibi birçok kahveyi gün yüzüne çıkararak ziyaretçilerimizle buluşturuyoruz. Bu doğrultuda "Anadolu'nun Kayıp Kahveleri" adlı kitabın yazarı Atilla Narin Bey ile çalışmalarımızı yürütüyoruz. Ayrıca Safranbolu'da yetiştirilen ilçeye adını veren Safran bitkisini kullanarak Safranlı kahveyi misafirlerimizin beğenisine sunduk. Bunun yanında meyve aromalı kahve ve Soğuk Türk kahvesi gibi yenilikçi kahve üretme konusunda Ar-Ge çalışmalarımız devam etmektedir. 
Safranbolu için Türk kahvesini ve Safranbolu Türk Kahve Müzesi'ni çekici kılan özellikler nelerdir?

İlk olarak Safranbolu'nun UNESCO somut olmayan kültürel miras listesinde yer alması ve aynı zamanda 2013 yılında Türk kahvesinin de somut olmayan kültürel miras listesine eklenen ilk içecek olması bizi ayıran önemli özelliklerden biri. Ayrıca tarihi araştırmalara baktığımızda 1828 yılında Safranbolu'ya en fazla giren ürünün kahve olması, 300 yıllık geçmişe sahip Arasna kahvehanesi gibi kahvehane kültürünün olması, bizim de bu kültürü anlatan bir yer olmamız çekici kılan özellikler arasında yer verilebilir. Müze kahvenin çekirdekten fincana tüm detaylarını görebileceğiniz, ilk kavurma aletleri, kavurma tavaları, soğudanlıklar, değirmenler, Cumhuriyet dönemine ait cezveler, Atatürk'ün son kez kahve içtiği fincanın replikası, Atatürk'ün telve ile çizilen resmi gibi tarihe 1şık tutan koleksiyonlarımızı sergiliyoruz. Aynı zamanda Safranbolu'nun kahvenin yanında servis edilen lokumla tanınması bizim ayırt edici özelliklerimizdendir. Ayrıca Safranbolu ile özdeşleşen menümüze eklediğimiz safran bitkisiyle hazırladığımız safranlı kahve yine turistler için ilgi odağı olmayı başarmıştır.

Müzeyi tanıtmak ve turizme açmak için ulusal ve uluslararası düzeyde hangi faaliyetleri yürütüyorsunuz?

Tanıtım faaliyetleri kapsamında sosyal medya platformları gibi dijital medya araçlarını yoğun olarak kullanmaktayız. Ancak gösterilen yoğun ilgi ile tanıtım faaliyetleri kapsamında yapılan uygulamalar bizim bireysel kontrolümüzden çıktı. Müzeyi deneyimleyen bloggerlar ve sosyal medya influencerları tarafından tanitılmaya başlandı. Ayrıca Kültür ve Turizm Bakanlığı'nın resmî sitesinde ve sosyal medya hesaplarında tanitımlar yapılıyor. Yerel ve ulusal medyanın yanında Safranbolu'da Türk kahvesi müzesinin olduğunu öğrenip müzemize gelen uluslararası TV kanalları ile programlar yapıyoruz. Bunun yanında özel davet edildiğimiz fuarlarda müze ve Türk kahvesi ile ilgili bilgilendirmeler yapıyoruz. Ayrıca şehrimizdeki üniversitenin Gastronomi ve Mutfak Sanatları bölümü ve şehirdeki diğer paydaşlarla iş birliği halindeyiz. İlerleyen dönemlerde Safranbolu kahve günleri etkinliği, workshop uygulamaları, Türk kahvesi sunum seremonileri gibi birçok projeyi hayata geçirmeyi planliyoruz.

\section{Safranbolu Türk Kahve Müzesi tur şirketlerinin gezi programlarnna dahil midir?}

Turlara dahil olmak için herhangi bir çabamız olmadı. Safranbolu ziyaretine gelen tur şirketleri ve rehberlerinin müzenin varlığından haberdar olmasından sonra misafirlerini müzeye getirmeye başladılar. Ama biz resmi bir anlaşma halinde değiliz. Sadece bireysel anlamda turlara dâhil edilmeye başladık. Bunun yanında müzenin fiziksel şartlarından dolayı tur şirketleriyle kalabalık gelen misafirlere hizmet verme konusunda zorluk çekiyoruz. Bu doğrultuda hem turlarla gelen misafirlere cevap verebilmek hem de müzede sergilediğimiz koleksiyonlarımızın sayısının artmasından dolayı müzeyi Safranbolu'nun önemli mimari eserlerinden biri olan Cinci Han'a taşıyoruz. 


\section{Sonuç ve Öneriler}

Gastronomi müzelerinin destinasyon çekim gücü olduğunun vurgulanması amacıyla yapılan bu çalışma Safranbolu Türk Kahve Müzesi'nde gerçekleştirilmiştir. Çalışmanın bulgular kısmında paylaşılan veriler görüşme tekniği ile elde edilmiştir.

Safranbolu Türk Kahve Müzesi hem maddi hem de manevi bir değer olan Türk kahvesinin korunması ve tanıtılması amacıyla kurulan ilk ve tek müzedir. Müzede Türk kahvesinin çekirdekten fincana uzanan sürecinin tüm basamakları gözlemlenebilmektedir. Bu basamaklar için gerekli olan ekipmanlar da müzede sergilenmektedir. Müzeyi her yaştan hem yerli hem de yabancı turistler ziyaret etmekte ve müzeyi ziyaret eden turistlerde kahve içme niyeti ve isteği oluştuğu görülmektedir. Ayrıca Safranbolu'nun lokumuyla meşhur olması ve Türk kahvesinin lokumla ikram edilmesi, safranlı kahve gibi yeni ürünlerin denenmesine olanak sağlaması da turistlerin müzeye olan ilgisini artırmaktadır. Müzenin tanıtımı için sosyal medya platformları ve diğer dijital mecraların aktif olarak kullanılması, müzenin bloggerlar ve influencerlar tarafından tanıtılması ve müzenin bölgedeki üniversiteler ile iş birliği içerisinde olması müzenin bilinirliğini artırmaktadır. Ayrıca herhangi bir resmi anlaşma olmamasına rağmen Safranbolu Kahve Müzesi tur şirketlerinin programlarına dahil edilmiş durumdadir.

Yapılan çalışma sonucunda şu önerilerde bulunulabilir;

- Gastronomi müzeleri ile ilgili akademik çalışmaların oldukça yetersiz olması alanyazında büyük bir eksiklik oluşturmaktadır. Bu sebeple müzenin konu alındığı daha geniş çaplı akademik çalışmalar yapılabilir.

- Gastronomi müzelerinin gastronomi turizmi ve destinasyonlar açısından daha çekici hale getirilmesi için tanıtım ve iş birliği ağı genişletilebilir.

- Sadece gastronomi müzelerini içeren bir kitapçık hazırlanıp özellikle tur şirketleri vasıtasıyla turistler müzelerin varlığından haberdar edilebilir.

- Ülkemizin yeteri kadar tanıtılamamış yöresel ve ulusal ürünlerinin korunması ve tanıtımının yapılması için gastronomi müzelerinin kurulması desteklenebilir.

- Safranbolu Kahve Müzesi'nin bilinirliğini artırmak için tur şirketleri ile resmi anlaşmalar yapılması ile müzenin bölgede yer alan tüm şirketlerin tur programlarına dahil edilmesi sağlanabilir.

\section{Kaynakça}

Acar, N., Çakırbaş, A. ve Çizmeci, B. (2019). Türk Kahvesi Tüketilen Mekanların Seçimini Etkileyen Faktörlerin Belirlenmesi: Nevşehir Örneği. Anemon Muş Alparslan Üniversitesi Sosyal Bilimler Dergisi, 7(1), 135-143.

Ağcakaya, H. ve Can, İ. I. (2019). Somut Olmayan Kültürel Miras Kapsamında Mutfak Kültürünün Sürdürülebilirliği: Türkiye'deki Gastronomi Müzeleri Örneği. Journal of Gastronomy and Travel Research, 3(4), 788-804.

Aksoy, M. ve Sezgi, G. (2015). Gastronomi Turizmi ve Güneydoğu Anadolu Bölgesi Gastronomik Unsurlar1. Journal of Tourism and Gastronomy Studies, 3(3), 79-89. 
Akyürek, S. ve Erdem, B. (2019). Gastronomy Museums as Sustainable Hangouts in Gastronomy Tourism: A Gastronomy Museum Proposal for Gümüşhane City, Turkey. TURIZAM, 23(1), 17-33.

Arslan, F. (2019). Tüketicilerin Kahve Tüketim Alışkanlıkları ve Kahve Dükkânı Tercihleri: Antalya İlinde Bir Araştırma. International Journal of Contemporary Tourism Research, 2, 224-234.

Atlas Obscura. (2021). Brazil's Coffee Palace. Erişim Adresi: https://www.atlasobscura.com/places/coffee-palace Erişim Tarihi: 21.04.2021.

Balcı, F. (2019). Cezveden Kültüre 40 Yıl: Türk Kahvesi ve Geleneği. Akademik Sosyal Araştırmalar Dergisi, 7(87), 315-328.

Bekar, A., Arman, M. ve Sürücü, Ç. (2017). Turizmde Çekicilik Unsuru Olarak Gastronomi Müzeleri: Marmaris Bal Evi Örneği. Akademik Sosyal Araştırmalar Dergisi, 5(42), 468477.

Ceyhun Sezgin, C. ve Akbıyuk, A. (2021). Dünyadaki Gastronomi Müzelerinin Tematik Analizi. Journal of Tourism and Gastronomy Studies, 9(1), 153-184.

Cömert, M. ve Sökmen, A. (2017). Türkiye'de Gastronomi Turizmi: Antalya'da Konaklayan Turistler Üzerine Bir Araştırma. Seyahat ve Otel İşletmeciliği Dergisi, 14(3), 6-26.

Çavdırlı, C. M. ve Gök, Ö. A. (2020). Müzeler ve Kültürel Mirasın Sürdürülebilirliği: Köstem Zeytinyağı Müzesi. Journal of Tourism and Gastronomy Studies, 8(3), 2241-2262.

Çavuş, A., Işık M. F. ve Yalçın, C. (2018). Gastronomi Turizmi Çekiciliği Açısından Zigana Yöresi. Atatürk Üniversitesi Sosyal Bilimler Enstitüsü Dergisi, 22, 3043-3057.

Çetin, M. ve Küçükkömürler, S. (2019). Destinasyon Çekicilik Unsuru Olarak Gastronomi Müzeleri: Oleatrium Zeytin ve Zeytinyağı Tarihi Müzesi Örneği. Ankara Hacı Bayram Veli Üniversitesi Turizm Fakültesi Dergisi, 22(1), 1-17.

Girginol, C. R. (2018). Kahve: Topraktan Fincana. 8. Basım. A7 Kitap.

Gök, H. S. ve Şalvarcı, S. (2021). Türkiye'deki Gastronomi Temalı Müzelere Yönelik Çevrimiçi Ziyaretçi Deneyimlerinin İncelenmesi. Seyahat ve Otel İşletmeciliği Dergisi, 18(1), 120140.

Gökdeniz, A., Erdem, B., Dinç, Y. ve Çelik Uğuz, S. (2015). Gastronomi Turizmi: Ayvalık'ta Yerli Turistler Üzerinde Görgül Bir Araştırma. Journal of Tourism and Gastronomy Studies, 3(1), 14-29.

Gürsoy, D. (2005). Sohbetin Bahanesi Kahve. Oğlak Yayınları.

Halstead, R., Hazeley, J., Morris, A. and Morris, J. (2007). Far From the Sodding Crowd. Penguin Books.

İpar, S. M. (2011). Turizmde Destinasyon Markalaşması ve İstanbul Üzerine Bir Uygulama, [Yayınlanmamış Yüksek Lisans Tezi]. Balıkesir Üniversitesi.

Kaşlı, M., Demirci, B. ve Kement, Ü. (2014). Gastronomik Deneyimlerin Tekrar Ziyaret Niyetine Etkisi: Eskişehir Örneği. 15. Ulusal Turizm Kongresi (13-16 Kasım), Gazi Üniversitesi, Ankara.

Kaya, G. ve Toker, S. (2019). Kahve Tüketim Alışkanlıklarının İncelenmesi: İstanbul Örneği. International Journal of Economics, Politics, Humanities \& Social Sciences, 2(3), 146-164.

Kefeli, E., Şahin, Ö. ve Yarmacı, N. (2020). Üçüncü Nesil Kahve İşletmelerinde Türk Kahvesinin Yeri: İstanbul Örneği. Uluslararası Batı Karadeniz Sosyal ve Beşeri Bilimler Dergisi, 4(2), 130-147.

Koca, N. ve Ersöz Tüğen, A. (2020). Somut Olmayan Kültür Miras Listesinde Bir değer Olan Türk Kahvesine Coğrafya Perspektifinden Bakış. Uluslararası Sosyal Bilimler Dergisi, 5(1), 347-362.

Köroğlu, Ö., Balıkoğlu, A., Köksalanlar, A. A. ve Türkmen, M. T. (2020). Müzecilik ve Müze Rehberliği. Detay Yayıncilık. 
Küçükkömürler, S., Şirvan, U. N. B. ve Sezgin, A. C. (2018). Dünyada ve Türkiye'de Gastronomi Turizmi. Uluslararası Turizm, İşletme, Ekonomi Dergisi, 2(2), 78-85.

Long, L. M. (2004). Culinary Tourism: A Folkloristic Perspective on Eating and Otherness. Lucy M. Long (Ed.), Culinary Tourism içinde, The University of Kentucky, Lexington.

Mankan, E. (2017a). Destinasyon Pazarlamasında Çekici Bir Faktör Olarak Türkiye'deki Gastronomi Müzeleri Örneği. International Periodical fort he Languages, Literature and History of Turkish or Turkic, 12(4), 641-654.

Mankan, E. (2017b). Dünyadaki Gastronomi Müzeleri Üzerine Bir Değerlendirme. International Periodical fort he Languages, Literature and History of Turkish or Turkic, 12(1), 157-176.

Özdemir, G., Dülger Altıner, D. (2019). Gastronomi Kavramları ve Gastronomi Turizmi Üzerine Bir İnceleme. Erzincan Üniversitesi Sosyal Bilimler Enstitüsü Dergisi, 12(1), 1-14.

Quan, S. and Wang, N. (2004) Toward a structural model of the tourist experience: an illüstratör from food experiences in tourism, Tourism Management, Vol. 25, pp.297-305.

Resmî Gazete (1985). Milletlerarası Müzeler Konseyi (ICOM) Türkiye Milli Komitesi Yönetmeliği, 15.05.1985, 18755.

Sandıkçı, M., Mutlu, A., S. ve Mutlu, H. (2019). Mutfak Müzelerinin Sergileme Şekilleri ve Turist Rehberlerinin Etkisi: Şanlıurfa Hacıbanlar Evi Mutfak Müzesi Örneği. Turist Rehberliği Dergisi, 2(2), 104-112.

Sun, G. ve McLaughlin-Eastham, R. (2019). Dubai'de 'Gelecek', 'Kahve' ve 'Parfüm' Müzelerinden Kur'an Parkına Farklı Seçenekler. Erişim Adresi: https://tr.euronews.com/gezi/2019/08/26/dubai-de-gelecek-kahve-ve-parfummuzelerinden-kur-an-parkina-farkli-secenekler Erişim Tarihi: 21.04.2021.

Temeloğlu, E. ve Akdeniz, D. (2020). Tüketicilerin Türk Kahvesi Hakkında Bilgiye Sahip Olma Algı Seviyelerinin Demografik Özelliklere Göre Karşılaştırılması. Uluslararası Türk Dünyası Turizm Araştırmaları Dergisi, 5(1), 116-126.

Türkiye Kültür Portalı (2021). Emine Göğüş Mutfak Müzesi-Gaziantep. Erişim Adresi: https://www.kulturportali.gov.tr/turkiye/gaziantep/gezilecekyer/emine-gogusmutfak-muzesi Erişim Tarihi: 11.04.2021.

Ürer, H. (2010). Osmanlı'da Kahve/Kahvehane Kültürü ve Salihli'den Bir Kahvehane Örneği "Himaye-i Etfal". Sanat Tarihi Dergisi, 19(2), 1-26.

Yeşilyurt, H. ve Arıca, R. (2018). Mutfak Müzesi Ziyaretçilerinin Deneyimlerinin İncelenmesi: Emine Göğüş Mutfak Müzesi Örneği. Türk Turizm Araştırmaları Derneği, 2(1), 60-70.

Yıldız, M. ve Yılmaz, M. (2019). Türkiye'de Gastronomi Turizmi Üzerine Bir Literatür İncelemesi. Sivas Interdisipliner Turizm Araştırmaları Dergisi, 2(4), 51-60.

Yılmaz, G. (2017). Gastronomi ve Turizm İlişkisi Üzerine Bir Değerlendirme. Seyahat ve Otel Isşetmeciliği Dergisi, 14(2), 171-191.

Yılmaz, H. ve Şenel, P. (2014). Turistik Bir Çekicilik Olarak Gastronomi Müzeleri. 15. Ulusal Turizm Kongresi (13-16 Kasım), Gazi Üniversitesi, Ankara.

Yüncü, H. R. (2010). Sürdürülebilir Turizm Açısından Gastronomi Turizmi ve Perşembe Yaylası. 11. Aybastı-Kabataş Kurultayı, 11, 27-34. 